\title{
Daoistički put ka jednostavnosti u romanu Pričanje Ursule Le Gvin
}

\author{
Artea D. Panajotović* \\ Alfa BK univerzitet, Fakultet za strane jezike
}

\section{Ključne reči: \\ kineska filozofija \\ naučna fantastika \\ dao}

vu vei

transformacija ličnosti

\section{Apstrakt}

Iako veza Ursule Le Gvin sa kineskim filozofskim sistemom daoizma predstavlja opšte mesto u razmatranjima njenog dela, ona u njima nije dublje istražena. U nastojanju da osvetli mali deo tog složenog odnosa, ovaj rad istražuje motiv jednostavnosti, jednog od ključnih pojmova daoističke filozofije i temelja daoističke prakse, u poslednjem romanu hainskog ciklusa Pričanje (2000). Na nivou osmišljavanja likova, proces ostvarivanja jednostavnosti svoje uobličenje je dobio u razvojnom putu protagonistkinje romana. Istraživačko putovanje Sati Das, posmatrača Ekumena na planeti Aka, predstavlja put samospoznaje i ličnog preobražaja, ličnu potragu za jednostavnim. Ključne tačke na tom putu jesu upoznavanje drevnog, sada zabranjenog filozofsko-religijskog sistema Pričanja koji joj pruža novi model poimanja sveta i života, i složeni odnos sa antagonistom romana, službenikom totalitarnog sistema koji sada vlada planetom. Analiza pokazuje da postizanje jednostavnosti kod Sati Das dovodi do preobražaja lažnog (nesuštastvenog) sopstva u istinsko (suštastveno) sopstvo i otkriva duboku prožetost autorkinog shvatanja koncepta jednostavnosti daoističkom teorijom i praksom. (примљено: 6. августа 2021; прихваћено: 27. септембра 2021) www.anali.fil.bg.ac.rs

АНАЛИ ФИЛОЛОШКОГ ФАКУЛТЕТА

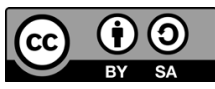

Alfa BK univerzitet Fakultet za strane jezike Palmira Toljatija 3 11000 Beograd, Srbija artea.panajotovic@alfa.edu.rs 
A u prašini iza nas otisaka stopala nema. (Ursula Le Gvin, Pričanje)

Jednostavnost je jedan od ključnih pojmova daoističke filozofije i temelj daoističke prakse. Ona tvori stabilnu osnovu za razvoj bića, pa je kod Lao Cija (老子) nalazimo kao ideal kako zajednice tako i pojedinca: iz nje se i na društvenom i na individualnom planu rađaju harmonija, mir i sigurnost. Misao stare Kine kao svrhu čovekovog postojanja u svetu ne postulira progres, već ravnotežu. Stoga razvoj u ovom kontekstu ne treba posmatrati kao napredak ili uvećavanje (znanja, bogatstva i sl). Razvoj za daoiste predstavlja povratak korenu i odbacivanje nepotrebnog, pa ga karakteriše centripetalno pre nego centrifugalno usmerenje, sabiranje a ne raspršivanje. Jednostavnost, pak, ne donosi samo mir i spokoj, sigurnost i ravnotežu: ona je direktan put do same suštine bića, do tamnog, umu i rečima nedostupnog ali iskustvu dostižnog izvora postojanja - daoa (道).

Koncept jednostavnosti ima istaknuto mesto u delu Ursule Le Gvin (Ursula Le Guin), autorke poznate po svojoj privrženosti daoističkoj filozofiji, i ona mu pristupa iz više uglova. Uticaj daoističkog shvatanja jednostavnosti, na primer, jasno je uočljiv u dijahronijskom razvoju hainskog ciklusa. Hainski ciklus romana, sa sazrevanjem Ursule Le Gvin kao stvaraoca, kreće se ka sve većem pojednostavljenju i pročišćenju pripovedne linije. Prateći romane po hronologiji objavljivanja, primećuje se kako sloj po sloj eksternih i nebitnih detalja nestaje iz sveta Ekumena, zajednice svetova. Najpre više nema rata protiv neprijatelja, a u narednim romanima gubi se i sam neprijatelj. Ekumen se sve više približava idealnoj vlasti po Lao Ciju: plaćanje danka se u poznijim romanima gubi, kao i čvrsta kontrola nad planetama članicama primetna u prvim romanima ciklusa. Na nivou pojedinačnih romana, uočavamo osmišljavanje zajednica zasnovanih na principima jednostavnosti, te ocrtavanje puta koji pojedinac prelazi kako bi do nje došao. Kod Ursule Le Gvin stanju jednostavnosti teže svi likovi i društva koji prate nalog svoje unutrašnje prirode, a praćenje unutrašnje dinamike u daoizmu je ujedno i praćenje naloga neba. Postizanje jednostavnosti nije jednostavno, posebno zato što je ona protivna opštem pravcu kretanja sveta. U skladu s tim, kao i u svim drugim aspektima daoističke filozofije, ospoljavanje je sekundarno i dolazi kao posledica - nema jednostavnog dela bez jednostavnog bića: jednostavnost nije u činu i ispoljavanju, već proizlazi iz pročišćene duše i pročišćenog uma. Stoga je značajno uočiti razliku koju Ursula Le Gvin na tragu kineske misli pravi između pojednostavljivanja i regresije ili degradiranja. Lao Ci (2003: 52) savetuje da sve komplikovano treba svesti na jednostavno jer komplikovano zapravo i jeste sastavljeno od jednostavnog. Oko je to koje stvari vidi kao komplikovane ili jednostavne: neka bude takvo da vidi jednostavno. To ne podrazumeva uprošćavanje stvari. Jednostavno u stvarima nije banalno, besmisleno, mehaničko ili površno, već ono suštinsko. Daoizam nalaže okretanje suštini stvari, oslobađanje od njene površne složenosti i uočavanje onog jednostavnog u svemu - njegove plodne i stvaralačke biti: „Veliko drvo širokog stabla izraslo je iz malog pupoljka, [...] put od hiljadu lija započinje jednim korakom“ (Lao C, 2003: 52). Suština putovanja je 
korak, suština drveta je seme. Kao polazište se uzima ono suštinsko i bitno - a to je u svojoj srži jednostavno. Za daoiste mudrost je prozreti (kroz) kompleksnost sveta, svesti bivanje u njemu na jednostavnost i na taj način otvoriti put ka jednom.

Razvoj i preobražaj ličnosti koji vodi do autentičnog jestanja u daoizmu se javlja kao put jednostavnog i mekog, put oslobađanja od zabluda uma i iluzornih sadržaja misli i osećanja. Autentično jestanje se tako pokazuje ne kao stanje do koga treba stići, već stanje kome se treba vratiti, što je iskazano u jednoj od ključnih Lao Cijevih formulacija da je put daoa povratak. Taj daoistički put ka jednostavnosti podrazumeva proces pročišćenja. Kako bi se otkrilo nesputano, slobodno biće koje vlada sobom, nesmetano diše, kreće se, misli i oseća, primese poput egoizma, straha, nesigurnosti, navika i uslovljenosti moraju se prepoznati i odbaciti. Sve one modifikuju i izobličuju autentični izraz, sprečavaju jednostavnost i neposrednost, te čini osobu slabom i krutom. Oslobođena, pročišćena individua je meka i upravo stoga jaka. Džuang $\mathrm{Ci}$ (莊子) ovo iskazuje sledećim rečima:

Izbriši iluzije volje, ukloni zamke srca, oslobodi se upletenosti vrline, otvori prepreke na Putu. Položaj i bogatstvo, priznanje i vlast, slava i dobit - ovo je šest iluzija volje. Izgled i držanje, püt i lik, narav i stav - ovo je šest zamki srca. Gnušanje i želja, radost i srdžba, tuga i sreća - ovo je šest upletenosti vrline. Odbijanje i prihvatanje, uzimanje i davanje, znanje i umenje - ovo je šest prepreka na Putu. Kada ove četiri grupe od šest odličja prestanu da ključaju u grudima, tada ćeš postati uspravan; uspravan, bićeš miran; miran, bićeš prosvetljen; prosvetljen, bićeš prazan; a prazan nećeš činiti ništa, a opet ništa neće ostati neučinjeno. (Zhuangzi, 2013: 197)

U istraživanju ovog procesa, Ursula Le Gvin junake svojih romana često šalje na duga, iscrpljujuća putovanja. Put je jedan on najznačajnijih toposa daoizma, i ova autorka često koristi taj motiv u svojim delima. Praktično nema junaka u hainskom ciklusu, od Rokanonovog sveta do Pričanja, koji se ne poduhvata putovanja koje ispituje granice njegove izdržljivosti i koje će mu promeniti život, a u koje se on po pravilu upušta „bez ikakvih prethodnih poznanstava, uticaja, bez ikakvog privatnog vlasništva" (Vučković, 2020: 142). To je uvek putovanje kroz teško prohodne, mahom zimske krajolike, putovanje koje svojom ekstremnošću protagonistu dovodi do suočavanja sa osnovama njegovog bića i duboke samospoznaje i njome uslovljene spoznaje sveta. Posle ovakvog puta, sve nedoumice junaka se razrešavaju i ostaju mu tehničke poteškoće sprovođenja namere, dok se ta namera iskristalisala na putu.

Bitno je naglasiti da su kod Ursule Le Gvin sva putovanja i putovanja delanja i putovanja spoznaje. Rafail Nudelman u ogledu „Pristup strukturi SF-a Ursule Le Gvin“ (An Approach to the Structure of Le Guin's SF) kaže: „putovanje, kao kretanje ka istovetnosti svega sa svime [...] postaje put ka sebi, a istovremeno i ka sjedinjavanju sa drugima, tj. od sebe“ (Nudelman, 1975: pasus 35). Piter Brig (Peter Brigg) razmatrajući arhetip putovanja u stvaralaštvu ove spisateljice iznosi zapažanje da „[k]ada pisac ospolji putovanje duše u formi fikcije, krajolik putovanja poprima me- 
taforički značaj mita i saznanje do koga dovodi i putnika i čitaoca postaje paradigma svekolikog ljudskog iskustva“ (Brigg, 1979: 36). Spoljašnje delanje je neodvojivo od unutrašnje spoznaje, svaka spoznaja se odražava na delo, svako delo utiče na sopstvo. Kako autorka sama kaže u predgovoru za priču „Prostranija od carstava i sporija“, „Ukoliko [...] fizičke akcije [ne] odražavaju psihičke, [ukoliko] dela [ne] izražavaju ličnost, meni su avanturističke priče veoma dosadne; često deluje da što je više akcije prisutno, to se manje dešava. Očigledno je da mene zanima šta se dešava unutra“" (Legvin, 2013: 192). Život i rad su nerazdvojni za poslenike Ekumena: u Čoveku praznih šaka Genli Ai će uspeti da dovede Ekumen na Geten tek kada misija postane život i ispunjavanje cilja se poistoveti sa očuvanjem života. Slično tome, Sati Das u poslednjem hainskom romanu Pričanje (The Telling, 2000) spaja posao posmatrača sa ličnim putem spoznaje.

Kroz opis filozofsko-religioznog sistema Pričanja i zajednice zasnovane na njemu, roman Pričanje istražuje način života koji ishodi iz neizrecive osnove bivstvovanja veoma bliske daou, dok kroz životnu priču Sati Das opisuje put pojedinca do ostvarivanja takvog života. Sati je Zemljanka, posmatrač Ekumena na planeti Aka zadužen za izučavanje istorije i književnosti ove zemlje. Međutim, od njenog polaska sa Zemlje do dolaska na Aku prošlo je više decenija i sve se promenilo. Aka se pretvorila u tehnokratsku distopiju: ona više nema istoriju i književnost, zatrla je svoju prošlost zarad vrtoglavog tehnološkog razvoja. Sati od Ekumena dobija zadatak da ode u gradić Okzat-Ozkat na krajnjem istoku kontinenta kako bi pronašla ostatke zabranjene religije Pričanja i pokušala da spase ono što je od ove bogate tradicije ostalo. Da bi ispunila svoju misiju, Sati odlazi u potragu za prošlošću i duhovnošću ove planete. Taj će put ujedno biti i njen put ka mirenju sa sopstvenom prošlošću, put samospoznaje i put do jednostavnosti. Suzan Bernardo (Susan Bernardo) i Grejam Marfi (Graham Murphy) naglašavaju da je „uticaj daoizma na Ursulu Le Gvin posebno izražen u načinu na koji razvija lik Sati, protagonistkinje [Pričanja]" (Bernardo/Murphy, 2006: 80). Tumačenje koje ću u daljem tekstu ponuditi će, nadam se, obogatiti razumevanje ovog dela i bolje osvetliti razmeru njegove prožetosti daoističkom filozofijom.

Na početku romana, glavnu junakinju susrećemo kao osobu na rubu potpune dezintegracije: Sati Das oseća da oko vrata ima sapon koji je sve jače steže. Potpuno je preplavljena traumatičnom prošlošću, strahom, nesigurnošću, besom, nesposobnošću za funkcionisanje u spoljnom svetu, akutnim osećanjem odsustva neposrednosti i smisla u životu. Priča o Sati Das otpočinje sledećim rečima: „[N]oć je ista na svim svetovima. Ništa drugo do odsustvo svetlosti“ (Legvin, 2000: 5). Razmišljajući o tami, ona na izvestan način anticipira put kojim će od pojavnog, promenljivog, haotičnog i komplikovanog poći u skriveno, tiho i jednostavno. Na ovom putu od represivne Zemlje preko haotične akanske prestonice Dovze do Okzat-Ozkata, gradića na kraju sveta koji čuva staru duhovnu tradiciju Pričanja, i Silongovog skuta, poslednjeg hrama Pričanja na vrhu najviše planine na kontinentu, Sati Das će, deo po deo, odbacivati nanose i ožiljke prethodnog života otkrivajući svoju suštinu.

Da bi postala autentično, slobodno i stvaralačko biće, Sati mora da se oslobodi ega, pročisti od zbrke osećanja koja je sada preplavljuju i sabere oko sebe. Treba 
da prevlada represiju razuma i njegovu opsesivnu potrebu za redom, određenošću, preciznošću, za potpunom izdiferenciranošću i jednoznačnošću - razuma spremnog da uništi svet kako bi ga definisao i saobrazio sebi i svojim pravilima, ${ }^{1}$ kome nije važna istina već samoodržanje i sigurnost po bilo koju cenu. Dejvid Rouzen (David Rosen) i Elen Kraus (Ellen Crouse), istražujući paralelu između daoizma i razvojne psihologije, objašnjavaju: „Ego se može shvatiti kao samozaštita ili podvojenost koja stvara teskobu i izolovanost. [...] Mudrost proističe iz odricanja od ega, što omogućava ostvarivanje duhovne celovitosti ili integriteta“" (Rosen/Crouse, 2000: 121). Sati mora da nadiđe ego da bi došla do pravog saznanja.

Pored hipertrofiranog razuma, Sati Das treba da prevlada i nesigurnost, sećanje, bol i strah koji su se nakupili u njoj: „Znala je premnogo pesnika. Znala je više pesnika, više poezije, znala je više bola, znala je više nego što je bilo ko trebalo da zna. Stoga je pokušala da ne zna. Da dođe na mesto gde ništa ne zna“ (Legvin, 2000: 64). Lao Ci (2003: 53-54) kaže:

Dobri ljudi iz starine (koji su) ostvarili (sjedinjenje sa) daoom, nisu želeli da narod ima uvid (u nebitne stvari), već da (uvek) bude neuk (za stvari izvan daoa). ${ }^{2}$

U Praznim rukama Radosav Pušić kaže da „[u] procepu između sopstvenog bića i bića sveta, sopstvo nalazi meru koja sve čega se dotakne dovodi do skladnog i harmoničnog dela“ (2015: 184). Upravo se negovanjem te praznine između sebe i sveta može sa svetom stupiti u kreativan odnos koji preobražava i pojedinca i svet. Čist,

1 Alan Vots (Alan Watts) objašnjava kako se ova odlika razuma odražava u zapadnjačkoj nauci: „[N]amera zapadnjačke filozofije i nauke je da zarobe univerzum u mreže reči i brojeva, te stoga uvek postoji iskušenje da se pravila, ili zakoni, gramatike i matematike pomešaju sa istinskim funkcionisanjem prirode" (Watts, 1981: 42). Jung takođe govori o potajnoj težnji „da se psihička stvarnost nadomesti jednim prividno sigurnim, veštačkim, ali samo dvodimenzionalno zamišljenim svetom, u kojem je životna stvarnost dobro prikrivena jasnim koncepcijama. Doživljaj je odvojen od svoje supstance, a nju su zamenili puki nazivi koji, nadalje, treba da zauzmu mesto realnosti“ (Jung, 2015: 148). U ovom kontekstu zanimljivo je i Suzukijevo (Suzuki/From, 1973: 19-22) isticanje razlika u načinu na koji Zapad i Istok pristupaju stvarnosti kroz analizu upotrebe motiva cveta kod Tenisona i Bašoa.

2 U Levoj ruci tame ovaj princip je predstavljen kroz mistički kult Handare koji naglašava značaj odučavanja, „neučenja“. Po Handari, ne treba naučiti ništa - istinsko znanje dolazi iz odučavanja, krčenja prostora i stvaranja praznine. Da bi se osoba vratila sebi i stupila u kontakt sa svojom duhovnošću, od mnogo više toga treba da se odvikne i mnogo više toga treba da zaboravi nego da nauči. Objašnjavajući laocijevski pojam bezimene jednostavnosti, Radosav Pušić objašnjava da „[l]išena suvišnih sadržaja, bića se sabiraju oko neukrašenog i golog bivstva" (Pušić, 2015: 209). Handara je stoga nepoverljiva prema znanju i teži ne-znanju, odučavanju, zaboravljanju jer znanje povlači sa sobom tumačenje, tumačenja je mnogo i ona vode u delanje, a delanje zasnovano na tumačenju znanja može biti (kako se u ovom delu pokazuje) izuzetno opasno. Dok je znanja mnogo, ne-znanje je jedno. Ono prekida tok tumačenja i donošenja sudova o svetu. Ne-znanje nije isto što i neznanje ili pogrešno znanje, jer i pogrešno znanje vodi tumačenju i delanju. Ne-znanje je potpuno ukidanje znanja, prekidanje niza znanje-tumačenje-delanje i zasnivanje drugačijeg načina postojanja u svetu. Handarate teže neznanju, koje je zapravo praznina u središtu bića, slično Lao Cijevoj (2003: 69) metafori praznine u točku u kojoj se paočanici spajaju i postaju upotrebljivi. Prema učenju Handare, ne-znanje vodi ne-delanju, što je esencijalno daoistička misao: delanje iz ne-znanja je isto što i delanje iz praznog (vu vei). U prepuštanju neprekidnom toku promena u pojavnom svetu Handarate pronalaze osnovu za delanje u skladu s prirodom, koje u neprestanoj promenljivosti pronalazi spokoj a u haotičnosti mirno mesto. 
raščišćen prostor oko sebe i u sebi dozvoljava da se iskaže ova heraklitovska mera koja je čoveku dodeljena kosmičkom igrom - njegova mera beskraja. Sati namesto praznine oko sebe ima ljušturu od metaiskustva - emocija i misli koje nisu plod slobodne interakcije sa svetom, već je udaljavaju od takve interakcije. ${ }^{3}$ One ispunjavaju procep između njenog bića i sveta, izolujući je i sasvim odvajajući od njega. Zato je Satin lični zadatak da prostor oko sebe potpuno pročisti i učini praznim. Na početku romana, um i srce su joj puni i ona ne može više ništa da primi. U njoj se nakupilo previše misli i osećanja. Stalno joj naviru sećanja sa Zemlje koja obnavljaju bol, nemir i patnju koje ne uspeva da prevaziđe. Sećanja je opsedaju i ona ih iznova i iznova oživljava do najsitnijih detalja. Ono što joj je potrebno jeste novi početak, nova šansa, praznina koju će, ako bude htela, ponovo moći da ispuni. Na kojoj god planeti bila um/srce (sin, 心) ostaje isto i nosi svoj teret. Ovako puna sećanja i patnje, ne može da primi ono što Aka ima da joj ponudi. ${ }^{4}$

Sati je izuzetno senzibilna i Ursula Le Gvin je nije slučajno izabrala za protagonistu romana koji se bavi duhovnošću, duhovnom praksom i putem ka dubokim životnim istinama. Upravo zato što je toliko prijemčiva i otvorena, Sati će moći da otkrije tajna, skrivena i zabranjena učenja. Međutim, to je ujedno i uzrok njenog stanja očajanja, nesigurnosti, paralisanosti: dubokim proživljavanjem svakog iskustva ona sve prima u sebe - i dobro i loše, i poeziju i patnju - i za sve se vezuje. Iako ima mnogo trauma, nesigurnosti i problema, Sati je suštinski hrabra, i upravo je njena traumatična prošlost kvalifikuje za ovo putovanje.

Ona brodom na reci Erehi kreće u Okzat-Ozkat, na putovanje koje će biti i put samootkrića. Sama početna tačka njenog putovanja bremenita je simbolikom. Reka Ereha, koja treba da je odvede do Okzat-Ozkata, teče kroz prestonicu, velika, ali „delimično prekrivena i tako skrivena zgradama i kejovima" (Legvin, 2000: 14). Sati je nikada ranije nije videla, nije ni znala da ona postoji. Reka je daleko ispod zvaničnog dela grada, ispod impozantnih betonskih nasipa iznad kojih se izdižu visoke stambene zgrade i poslovne i administrativne kule. Sati uviđa da kroz temelje sterilnog, zagušljivog i zaglušujućeg veštačkog grada u kome je do tada živela teče živa voda. Pronašavši tu vodu, kreće putem koji će je odvesti do njenog izvorišta.

Daleko ispod užurbane tehnokratske metropole, izvan vidokruga sistema, nesmetano se odvija život kakav je nekada postojao. Voda traži najnižu tačku i u njoj nalazi stabilnost, a onaj ko se pripoji njenom toku čuva seme života:

3 Radosav Pušić u Ptici u suncu ističe da dao "ne ukazuje na neki meta dao. On ne može da sadrži vlastito nadilaženje“ (2012: 208). Tako se put stapanja s daoom pokazuje kao proces pročišćenja od metaiskustva, a postizanje jednostavnosti izjednačava s prosvetljenjem. Odsustvo meta- dovodi do prisustva daoa, tj. bivanja u daou. Metaiskustvo uništava autentičnost: ono okiva, zaustavlja i parališe. Guta svoj rep i zatvara svaku mogućnost kretanja. Suprotnost je stvaralaštva, kretanja i mekoće. Suprotnost je daou, koji po svojoj prirodi ne može imati meta-. Metaiskustvo je nužno vulgarno zato što je u potpunosti iskazivo, zato što mu je suština ograničenost, a cilj shvatljivost. Ono je plod nastojanja da se objasne neobjašnjivo i čudesno, da se obuhvati nemerljivo. Osnovna metaemocija je strah, a koren straha je u totalitarnim tendencijama uma. Metaiskustvo objašnjava i sakati iskustvo svodeći ga na „meru čoveka“, lažno i iskrivljeno tumačenje ovog pojma. Istinska mera čoveka je nemerljiva. Dovesti se na svoju meru znači dotaći svoj „deo“ beskonačnosti - probiti se kroz koprenu prolaznog i utemeljiti u neizrecivom, nemerljivom, nesvodivom, skrivenom, dubokom i tajnom.

4 Majk Kaden (Mike Cadden) nudi drugačije tumačenje uloge sećanja u ovom romanu (Cadden, 2005: 27). 
Ispod ogromnih betonskih kejova stajali su drveni dokovi i skladišta pocrnela od starosti; na sve strane kretali su se brodići slični vodenim bubama, posvećeni poslovima izvan pažnje Ministarstva trgovine; bile su tu i kuće na čamcima obrasle u rascvetalu lozu, s rubljem koje se lepršavo sušilo; smrad mulja dopirao je odasvud. (Legvin, 2000: 28)

Voda je jedan od ključnih koncepata daoizma, te ne čudi što Sati upravo rekom, a ne nekim drugim putem, ide $u$ središte jedne civilizacije $i \mathrm{u}$ istraživanje njene $i$ svoje duhovnosti. Alan Vots svoju knjigu o daoizmu naziva Dao: put vode. Meka, podatna, fluidna, neuhvatljiva, nezaustavljiva i nepobediva voda u samom je središtu daoističkog poimanja sveta:

Na svetu ništa nije mekše od vode,

ali je nijedna sila ne može savladati.

Nezamenljiva je.

Meko pobeđuje kruto,

gipko pobeđuje stameno. (Lao C, 2003: 181)

Što je bliža svom izvorištu, reka Ereha je sve raskošnija, oko nje je sve manje krutih, tvrdih, nepropustljivih, teških betonskih okova, koje najpre zamenjuju drvena pristaništa sa sve brojnijim prilazima, a onda i ona nestaju i reka teče prirodnim tokom u prirodnom okruženju. Tu postaje zapanjujuće široka - njena raskoš, zamah i snaga u gradu se nisu mogli ni zamisliti. Svojom vodom napaja polja koja se šire oko nje bez granice.

Sati je izuzetno lako da razgovara s ljudima na brodu, za razliku od „karikiranih japijevaca“ u Dovzi, „koji ne žele da komuniciraju sa ostalima ukoliko to nije vezano za posao" (Vučković, 2020: 144). Tamo, gde je sve bilo isplanirano, svi u žurbi i neodložnim poslovima, bila je tiha i rezervisana. Dok se u gradu svi drže zvaničnih stavova Korporacije, na brodu je sve drugačije. Ljudi pričaju: spontano, otvoreno, opširno. Komuniciraju. Govore ono što žele da kažu, iz potrebe za pričanjem. Pričanje čiji trag Sati treba da pronađe počinje ovde:

Slušala je priče o njihovim rođacima, porodicama, poslovima, mišljenjima, kućama, hernijama. Ljudi s kućnim životinjama putovali su rečnim brodovima, otkrila je, pogladivši krznato i umiljato mače-kuče jedne žene. Ljudi koji nisu voleli letenje ili su ga se plašili, opredeljivali su se za brodove, kako joj je to veoma iscrpno objasnio jedan pričljivi stari gospodin. Ljudi koji se nikuda nisu žurili kretali su se brodom i pričali jedni drugima priče. Sati je čula više priča nego svi ostali zato što ih je slušala bez prekidanja [...] Slušala je pohlepno, neumorno. Ove dosadne i fragmentarne priče iz običnih života nimalo je nisu gnjavile. [Sve ono što joj je nedostajalo u Dovzi,] sve ono što je bilo izostavljeno iz zvanične književnosti, herojske propagande, nalazilo se u njima. Ako bi morala da bira između heroja i hernija, za nju uopšte nije bilo nedoumica: hernije su bile njen izbor. (Legvin, 2000: 31-32) 
Sati su, dakle, potrebne reči, potreban joj je smisleni, spontani, neposredni dodir bez proračunatosti i zadnjih misli, čista ljudska potreba za kontaktom, pričom i nekritičkim, nepretencioznim, neuzvišenim, pa čak i banalnim iskazivanjem sebe. Ona, previše srećna što je izašla iz izolacije i hladnoće, još ne nazire da postoji nešto više i dublje iz čega pričanje izvire i na čemu govor raste. Ali sama činjenica da joj taj rasplinuti, široki, banalni, nepovezani govor, bez početka i bez kraja, bez svrhe i cilja toliko prija znači da je na pravom putu. Voda teče i govor teče, a Sati se polako penje ka njihovom izvoru.

Većina putnika iz grada iskrcava se u mestu koje vodi u odmaralište Eltli. Odmah iza toga, tri brane vode u gornji tok reke koji je sasvim drugačiji od prethodnog: „Blizu Eltlija Ereha je proticala kroz tri ustave, od kojih je jedna bila duboka. Iznad njih postajala je to drugačija reka - divljija, uža, brža, s vodom koja više nije bila [mutno] plavomrka nego vazdušno plavozelena“ (Legvin, 2000: 32). Posle brana reka je pročišćena od mulja i nanosa prljavštine i bistra, a takvo postaje $i$ iskustvo na brodu. Seljaci su stidljivi prema strancima i ćutljivi, bujica brbljanja je zamrla. Sati prija ova promena, ova zdrava tišina kao kontrast nepoverljivom uzdržavanju i skrivanju informacija u gradu. Sama, u tišini, okreće se prirodi. U jednom trenutku upada u neku vrstu transa: „Ceo taj deveti dan protekao je u transu svetlosti. Brod se lagano kretao. Reka, sada bistra poput vetra, proticala je tako tiho da je izgledalo da lađa lebdi iznad nje, između dva vazduha. [...] Zemlja i nebo, i reka koja vodi od jednog do drugog" (Legvin, 2000: 33-34). Nestala je ona nesigurna, izgubljena osoba na ivici histerije, te bi se moglo reći da se i Sati pročistila s rekom.

U daoizmu unutrašnja dešavanja i unutrašnje promene imaju nemerljivo veći značaj od spoljašnjih. Daoistički filozofi drže da je sve u čoveku samom i da on stvara svoju stvarnost i svoj svet: „Kada nam se neizgovoreni aspekti naših skrivenih emotivnih namera otkriju, pokazuju nam kako stvaramo svet projektovanjem značenja i fantazija“ (Young-Eisendrath, 2000: 137). Tako i Sati pomišlja da je ovo putovanje duže od onog od Zemlje do Ake. Rastojanje između dve planete, desetine svetlosnih godina, nesamerljivi su sa unutarnjim putovanjem na koje oseća da se otisnula. Zašavši u nemerljive dubine svog bića oseća da je otišla neuporedivo dalje nego kada je sa Zemlje došla na Aku. Spoljašnje putovanje, pokazuje joj se, ne može doneti promenu: Sati sa Zemlje, traumatizovana, puna besa i gorčine, straha i nesigurnosti, ista je ona Sati koja je došla na Aku. Moglo bi se čak reći da je sa sobom donela totalitarizam, da je njen sputani um morao da naiđe na sputanost oko sebe i nađe svoj pakao. Stoga je putovanje u Okzat-Ozkat kao put promene i preobražaja, put ka izvoru posle koga neće biti ista, duže od putovanja na Aku.

Na početku romana, Sati je zbrkana, haotična i nediferencirana skupina misli i osećanja sa veoma niskom samosvešću. Kad krene na put, izdvaja se Monitor kao njen zastrašujući, hipertrofirani i fanatični razum. Kroz njen odnos sa Monitorom prikazano je oslobađanje od dominacije ega koji ne dozvoljava ispoljavanje iracionalnog dela ličnosti i njeno integrisanje u celinu. Lik Monitora možemo protumačiti na dva, suštinski srodna, načina: kao alegoriju Satinog razuma ili kao ogledalo u kome ona jasnije vidi sopstvene slabosti. Ovaj nadzornik Korporacije vidljivo ne 
odobrava to što se ona kreće van glavnog grada i što je „puštena na slobodu“. Postaje jasno da se na ovo putovanje otisnula sa opasnim neprijateljem koji će učiniti sve da je drži na oku i spreči da vršlja po nazadnim zabitima njegove zemlje. Upozorava je:

„Postoje džepovi kulturne fosilizacije i nepopustljive reakcionarne aktivnosti u ovom području. Nadam se da ne nameravate da putujete izvan grada, u gorje. Tamo gde obrazovanje još nije stiglo i gde su domoroci grubi i opasni. Shodno mojoj nadležnosti u ovoj oblasti, moram da zatražim od vas da stalno budete u vezi s mojim uredom, da prijavite svako ilegalno upražnjavanje na koje naiđete i da nas obavestite ako planirate da negde putujete.“ (Legvin, 2000: 37)

Puna besa i prkosa, Sati snažno reaguje na Monitora, a onda se kaje. Nije usvojila ponašanje koje se očekuje od Posmatrača - nepristrasnost, tj. uzdržavanje od formiranja mišljenja - i želeći da radi na tome podseća se da ne sme da sudi. Biće potrebno vreme da shvati da je svako posmatranje nužno aktivno i subjektivno, da je u tome njegova vrednost. Sati se zapravo zbog sebe, a ne zbog svog posla, mora rešiti destruktivnih, sputavajućih osećanja i burnih reakcija koje joj ne dozvoljavaju da pronađe mir. Mora da shvati da je princip Ekumena po kome „mišljenje okončava prijemčivost“ (Legvin, 2000: 45) životni, a ne poslovni moto, kao i da mora da ovlada mislima i osećanjima, da ih upozna i prevaziđe, kako bi mogla da živi slobodno i zasnuje istinski odnos sa svetom ne iskrivljujući percepciju i osećanje sveta slabostima svoje ličnosti. Samo tako će moći da jasnost viđenja prenese i na ono što radi.

U Okzat-Ozkatu, upoznajući jednostavnost koja leži u osnovi filozofsko-religioznog sistema Pričanja, Sati pronalazi put do sopstvene jednostavnosti. Kada je jedan posvećenik pita koliko daleko želi da ide, koliko hoće da sazna o Pričanju, kaže: „Dokle god me vodiči budu ljubazno poveli“ (Legvin, 2000: 63). Sada je već otvorena da prihvati sve što joj se daje - sve što njeni vodiči mogu i žele da joj pruže i sve što ona može da primi. Prepuštajući se izučavanju Pričanja, polako se otvara za ono neobjašnjivo, tamno i čudesno u osnovi postojanja i iskustva, stiče značajne uvide u dinamiku odnosa između čoveka i sveta i polako razrešava kompleksnosti svog unutrašnjeg sveta spoznajom njihove jednostavne suštine.

U jednoj od prvih šetnji gradom, Sati zuri u vrh Silonga, najviše planine na kontinentu i svete planine Pričanja. Oko nje se okupljaju seljaci, grubih crta, deformisanih stopala, bezubi, i ona oseća da su tu da joj pomognu da gleda u planinu, da zajedno s njom učestvuju u tom religijskom činu. Ove ljude prisustvo Silonga mora da je oblikovalo. Sâmo posmatranje vrha koga sunce rastače, kome se samo obrisi naziru jer se spajaju sa svetlošću, jer su svetlost sama, oblik je meditativno-religijske prakse. Njihova duhovnost se oblikovala u suživotu s planinom i svetlošću. Planina prima i prenosi svetlost, prima milost i sipa je na druge. Odlazak na planinu je religijsko hodočašće i planina je mesto čuda: tamo se, kako kažu meštani, živi večno, u njenoj utrobi živi biće, obitava duh, smisao. Na njoj ljubavni čin traje tri stotine godina. Zato se ide na planinu, objašnjavaju joj ovi neugledni ljudi, vedro, 
veselo, nasmejano. A na nju se dolazi letenjem. Sati je zbunjena. Zbunjena je i zato što je ovo njen prvi kontakt s netotalitarnom, neekspanzionističkom verom. Počinje da uviđa da vera nije suprotnost slobodi. Ovi ljudi govore sasvim otvoreno sa neznankom o zabranjenim stvarima. Ali njihov otvoreni govor je zagonetka: kako letenjem? Letenjem koje daruje mistička praksa. Jedna žena na Satino pitanje da li avion može tamo da sleti odgovara sa „Nigde“. Avion ne može dovesti ni na jedno mesto vredno prisustva. Do najvrednijih mesta može se doći samo neobjašnjivim, magijskim, čarobnjačkim, alhemijskim činom. Monitor dolazi i meštani se raspršuju poput seni i utvara. ${ }^{5}$

Iako je uvek bila skeptična prema magiji, čudima i natprirodnom, iskustvo joj sada pokazuje da je natprirodno u prirodi samoj, da nije roba prevaranata već sastavni, esencijalni deo života. Na jednom času vežbanja vidi čoveka koji stoji u vazduhu. Prestravljena je: „Ništa u vezi sa Odijedinom [mazom koji vodi grupne vežbe] nije delovalo kao hokus-pokus, ali Sati je ovu grupu, i tihe, spore pokrete u tami, doživela kao sablasno čudne, ponekad i uznemirujuće; počela je da ih sanja" (Le Guin, 2000: 139). Mazovi, sveštenici ili posvećenici Pričanja, poriču natprirodno jer natprirodno je u prirodi, u životu, oni ga osećaju u svim aspektima življenja. Život je obogotvoren, on sam, on u sebi je božanstven - to mu nije dato kao milost, to nije neka viša spoljna sila unela u njega - to je njegov sastavni deo: „Božansko nije onostrano, nije 'izvan sveta'. Ono je duboko utkano u svet i sva bića" (Pušić, 2012: 122). Filozof Vang Čung (王充) iz dinastije Istočni Han u spisu O skladu iznosi čuvenu misao da su „Nebo i Zemlja ispunjeni energijama“, te da se „sva bića iz svoje nutrine rađaju“" (Pušić, 2012: 122). Sama činjenica života i postojanja je čudo. Pričanje je upravo potvrda ove spoznaje. Za Pričanje, kao i za daoizam, upoznavati život sam, sebe samog, ispitivati, ponavljati, pričati o životu i svetu jeste biti uronjen u čudesnost, u magiju, biti svedok i učesnik svakodnevne alhemije - alhemija je, dakle, u čoveku i u svakodnevlju. Shvatanje magije kao "dejstva odozgo“ ukazuje na neosvešćenost činjenice da je odozgo zapravo unutra.

Kada sazna da je Korporacija uništila i zatvorila radnju jednog od njenih prvih prijatelja i najistaknutijih pripadnika Pričanja Sotju Anga i da je on nestao, Sati izjeda krivica. Misli da je njeno prisustvo dovelo do toga. Međutim, maz Eljed joj daje drugi ugao gledanja na ovaj događaj: nisi ti kriva i nije on kriv. Krivica ne postoji. Vremena su teška i ponekad se ne može učiniti ispravna stvar. Čak, dodaje, verovatno je zbog tebe njegova radnja tako dugo opstala. Komšija ga je prijavio pre Satinog

5 Autorka razliku između Monitora i posvećenika Pričanja potcrtava i njihovim fizičkim izgledom. Monitorova koža je glatka, zategnuta, čvrsta, poput plastike, i odskače od lica meštana koja su izborana, puna ožiljaka, ispupčenja, udubljenja. Njihova je koža sećanje, u nju je vreme utisnulo svoje tragove, oblikovalo je, njome se poigralo. Oni nemaju savršenu kožu, niti savršen stas. Kao takva, njihova koža je savršena; njihova tela su savršena: skulpture vremena, dokaz njihove mekoće i podatnosti, predanosti igri sa svetom i uronjenosti u život. Oni utiču na svet i svet utiče na njih, oni oblikuju svet i svet oblikuje njih. Ne čuvaju se uticaja života, već se bacaju u njega, plešu i rvu se s njim. Monitor je, nasuprot njima, neprobojan za život, potpuno gladak, potpuno zategnut. Jasno ograničen. Kod ovih ljudi granica između njih i sveta je fluidna, svet ih menja i oni menjaju svet. On na njima ostavlja tragove: troši im odeću, piše po koži, izbija zube, šara ih bojama, natapa mirisima. Monitor je potpuno zaptiven: čista, ispeglana uniforma, glatko lice. 
dolaska i samo iz obzira prema njoj (kako ona ne bi videla njihove represivne mere) vlasti ovo nisu uradile mnogo ranije. Čovek ne može da vidi sve elemente situacije i stoga se mora osloboditi krivice. Lao Ci kaže:

Ah nesreće, sreća je u vama;

Ah sreće, nesreća je u vama.

Ko (je taj ko) zna njihov svršetak?

Nemaju one (u svom javljanju) nikakvih pravila.

Ispravno se začas okrene u neispravno,

dobro u trenu postane zlo,

Čovekova (neobjašnjiva) upletenost (u haotično bivanja)

odavno traje! (2003: 48)

Zlo se očas izmetne u dobro, dobre namere lako dobiju loš ishod. Stoga, zajednički je stav daoizma i Pričanja, čovek ne može zasnivati svoje delovanje na ovakvim kategorijama jer ne može sagledati posledice svojih dela. Svet je promenljiv i van naše kontrole, samim tim ni apstraktni principi nisu čvrsti i trajni jer se odnose na ovaj promenljivi, nestalni svet i njegov su deo. Svaka misao, oset, osećanje i princip nestalni su, nestabilni, podložni tumačenju i menjanju. Spoznaja da u ovom svetu nema apsolutne istine za koju može da se uhvati i koja bi je vodila kroz život Sati pogađa, ali ujedno i oslobađa. Šta god mislila ili osetila nužno je relativno. Iz pozicije haotične upletenosti ne može se razlučiti smisao sveta. Ne možemo, stoga, delanje zasnivati na očekivanim rezultatima jer ih ne možemo predvideti. Postupak, tako, može imati samo subjektivno ishodište, dok njegov ishod čoveku ostaje skriven. Jedino što Sati može jeste da postupa po svojoj prirodi, po svom osećaju, i tu stane. Da ne pokušava da utiče na događaje koji nisu u njenoj moći, da o njima ne brine i da ne zatrpava sebe osećanjima krivice ili zasluge. Činiti i pustiti. Tome mora da se nauči. Sistem koji izučava i ljudi koji mu pripadaju uče je tome. Izuzetno je teško osloboditi se krivice i zasluge, koji su emanacija i znak jakog ega. Njih je na putu ka jednostavnosti nužno ostaviti iza sebe, i zato Lao Ci naglašava skromnost (2003: 49, 83-84), pri čemu skromnost ne shvata kao odricanje ili askezu. Skromnost je čišćenje od uronjenosti uma u iluziju sopstvenog značaja i veličine. Skromnost, dalje, nije degradacija u banalnost i vulgarnost. Čišćenje ega nije odbacivanje plemenitosti misli i osećanja kao izraza hibrisa. Skromnost je okrenutost iskustvu a ne utisku - odbacivanje metaiskustva i postizanje samozaborava u činjenju. Plemenitost, lepota i moć kristališu se u skromnosti.

Sati dobija ponudu da ode u Silongov skut, jedini religijski centar koji je opstao na planeti, smešten na vrhu planine, skriven od sveta. Prihvatanjem ponude, $\mathrm{u}$ skladu sa odlukom da će primiti sve što njeni učitelji žele da joj daju, ona kreće na narednu etapu svog duhovnog putovanja. Tokom uspona na ovu planinu, Satin duhovni vodič joj pokazuje drveće veličine malog prsta i ona shvata da je to isto drveće u Okzat-Ozkatu veličine žbuna, a u Dovzi je hodala u hladu njegovih bogatih krošnji. Ono što je na Zemlji ili u Dovzi činilo okosnicu njenog iskustva (metaiskustvo, ego 
i teret prošlosti), što je bilo veliko, bogato, značajno i puno života, na Silongu će se smanjiti do granice nepostojanja.

Sati se na planini potpuno prepustila proživljavanju čistog trenutka i u njoj je sve manje misli: „Ovde u planinama postojalo je mnogo toga što nije razumela. Živela je u trenutku, poput deteta. [...] Bila je zadovoljna što hoda, zadovoljna što sedi na suncu, zadovoljna što stupa tragovima jedne životinje“ (Legvin, 2000: 134). Džuang Ci o ovakvom stanju odsustva pojmovnog obrađivanja čulnih utisaka govori kao o metodi kultivisanja uma:

Detence po ceo dan zuri a da niti jednom ne trepne - jer nema posebnih naklonosti u svetu spoljnih stvari. Kretati se ne znajući cilja, kod kuće sedeti ne znajući razloga, lutati i lunjati prateći druge stvari, s njima na istom talasu jahati - ovo je osnovno pravilo očuvanja života, ovo i ništa drugo. (Zhuangzi, 2013: 192-193)

Sati je prestala da broji dane: ustaje, penje se, spava. Predala se kretanju: „Odlučila je još pre no što su krenuli da se ne raspituje o tome gde se nalaze, kuda idu ili koliko im još predstoji. Držala se te odluke tim lakše što joj je ona dopuštala da se oseća [detinje] slobodno" (Legvin, 2000: 125). Doći do jednostavnosti znači približiti se jestanju jednog (daoa) i osloboditi se pojmova smisla, besmisla, istine. Samo biti. Takvo bivanje je ishodište daoističkog ideala delanja iz praznog (vu vei, 無爲). Prazno u ovom kontekstu ne treba shvatiti kao ništa, ono je čisto jeste: „Samo stanje, sam vid stvarnosti koju jedno otkriva, nisu ni smisleni, ni besmisleni, ni istiniti, ni neistiniti, oni, naprosto, samo jesu“ (Pušić, 2012: 214). Na planini nema puta, nema staze, jedini putokaz su mape ispisane poetskim jezikom. Pričanje ovim ukazuje na to da nema puta do najvišeg znanja, već da postoje samo naznake koje čovek sam mora tumačiti i naći im svoje značenje. Takođe, da je taj put nemoguće opisati, da je nemoguće dati uputstva drugome da $i$ on njime pođe: Sati ne zna imena sela $i$ mesta kroz koja prolaze. Put se stvara dok se njime ide i, kako kaže Ursula Le Gvin, ne ostavlja otiske stopala u prašini - nestaje za nama. On, Sati Das otkriva, postoji samo dok se njime hoda.

Pred kraj putovanja „Svi Satini snovi [...] bili su o jednom glasu koji je mogla da čuje, ali ne i da razume, o dragulju koji je našla, ali ga nije mogla dodirnuti“ (Legvin, 2000: 132). Sledećeg dana, „[j]edan napev uobličio se sam od sebe u Satinom otupljenom umu: vratiti se da bi se išlo napred, ne uspeti da bi se uspelo. Spustiti se da bi se popelo, ne uspeti da bi se uspelo" (Legvin, 2000: 132). Približavajući se kraju svog puta, ona dolazi do dubokih uvida o osnovama i počelima sveta koji su zajednički daoizmu i Pričanju.

Kada dođe u Silongov skut, iznad nje se pojavljuje helikopter i razbija o stene na ulazu u svetilište. U njemu je jedva živi Monitor. On, dakle, prati Sati do samog kraja, po cenu ugrožavanja svog života. Odijedin, Satin duhovni učitelj, kaže joj da treba da razgovara s njim i čuje šta ima da joj kaže. Ako pratimo tumačenje po kome je Monitor deo Satine psihe, ovo ukazuje na staru mudrost koju zastupa i daoizam: 
upoznaj sebe. Na tragu iste ideje Jung ističe da ništa ne možemo da promenimo ukoliko ga ne prihvatimo: osuđivanje ne oslobađa, već pritiska (Jung, 1958: 339). Sati dugo odlaže ovaj susret, ali u jednom trenutku odlazi kod Monitora. Gruba je, ironična i nepoverljiva prema njemu i ravnodušna prema njegovom bolu. Oseća snažne emocije: mržnju, prezir, bes i veliku neprijatnost i stid jer su zatvoreni u skučenom prostoru šatora: „Sve što je želela bilo je da je na razdaljini od njega“ (Legvin, 2000: 154). ${ }^{6}$ Kaže mu:

„Znam ko si ti. [...] Ti si moj neprijatelj. Iskreni vernik. Pravednik u pravednoj misiji. [...] Zaštićen Bogom. Ili Državom. Ili već nekom laži koja prikriva njegovu zavist, sebični interes, kukavičluk i pohotu za vlašću. Bilo mi je, međutim, potrebno izvesno vreme da te prozrem. Ti si mene odmah prozreo. Znao si da sam ti neprijatelj. Da nisam pravednik.“ (Legvin, 2000: 156)

Posle ovog prvog neprijatnog susreta, Sati polako počinje da razgovara s Monitorom koji sada više nije bezimeni nadzornik, već postaje osoba po imenu Jara. Isprva mu uopšteno priča o svom iskustvu totalitarizma na Zemlji, ne pominjući nikakve lične događaje. No i ovo je uznemirava, počinje da se trese i tera sebe da zaćuti: „Odveć se približila. Uistinu odveć. Pogrešno“ (Legvin, 2000: 163). Duboko u sebi Sati čuva veliki bol koji je nedostupan, zatvoren i skriven. Njena najveća trauma još uvek je neizgovorena, i to stoga što ne sme da je izgovori. Ovde se jasno ocrtava suštinska razlika između neizrecivog i neizrečenog. Neizrecivo rečima daje slobodu, dar igre i kreativnosti - ono je podloga za reči, suština koja nejasno prosijava iz izgovorenog i boji ga smislom. Neizrečeno je zabrana, strah i varka, iluzija da ćutanje može učiniti da nešto nestane. Dok je neizrecivo tišina u središtu reči, neizrečeno je prećutkivanje koje se kamuflira neslobodnim i manipulativnim rečima lišenim smisla jer im cilj nije da iskažu svoju suštinu, već da skrenu pažnju s nečeg drugog. Ovakve reči ne proizlaze iz svoje nutrine. Većina govora je zapravo prećutkivanje - reč vrlo retko dolazi iz sebe. Zato takva reč u poeziji, mističkim, religijskim i filozofskim tekstovima ima ogromnu snagu. Čovek se mora osloboditi prećutkivanja da bi mogao da zaćuti. A to čini upoznavanjem sebe, rušenjem unutrašnjih barijera i osvešćivanjem sadržaja svog bića, što podrazumeva i suočavanje sa strahovima, patnjama i bolom i njihovo iskazivanje. Kako se pokazuje, mnogo se mora ispričati da bi se zaćutalo.

Jara takođe progovara o svojoj prošlosti i otkriva da se oduvek trudio da zadovolji druge i bude što bolji. Razum sam po sebi nije negativno obojen, ali su okrenutost drugima, potreba za samopotvrđivanjem, odobravanjem i dominacijom dovele do njegove degeneracije i hipertrofije. On je, zapravo, sve vreme nesvesno težio Silongu, težio da se vrati smislenosti, a to je činio pod izgovorom fanatične mržnje prema

6 Ova intenzivna odbojnost ukazuje na to da i dalje postoji snažna vezanost. Proces oslobađanja podrazumeva suočavanje sa vezanošću, njeno preispitivanje, razlaganje, rastakanje, dovođenje do besmisla. Čovek se može osloboditi nečega tek kad ga iznese i upozna, prihvati, pomiri se s njim. Ako ima potrebu da od njega beži, da se od njega skloni, znači da mu je ono bitno. Intenzitet emocije, ma kakav bio njen kvalitet, ukazuje na vezanost za njen predmet. 
Pričanju i Sati. Otkriva da ga nije Korporacija poslala da je prati, već je to sam tražio. A kad je jednom stigao u okrilje Pričanja, Okzat-Ozkat, nadređeni su ga prepustili samom sebi, oglušujući se o njegove očajničke izveštaje da Sati (a i njega s njom) treba hitno vratiti u Dovzu. Sam se, dakle, okružio vanracionalnim - onim što mrzi i što ga ujedno neobjašnjivo i nezaustavljivo privlači. I sam se, na jedan čudan način, priklonio vanracionalnom kada je, suprotno nalogu Korporacije, krenuo u potragu za Sati na Silongu, znajući da će zbog toga biti strogo kažnjen. Time je stupio na put samoponištenja i samooslobođenja.

Dovedeni na svoju bivstvenu meru, Jara i Sati sada razgovaraju na sasvim drugačiji način - bez ograda i zidova između sebe, ne moraju više da viču kako bi se čuli i da od svojih stavova prave hiperbolisane groteske da bi ih ovaj drugi shvatio. Njihova komunikacija postaje mirnija, finija, suptilnija i tiša. Tako, tek kad prihvati i sasluša deo sebe koji je toliko dugo potiskivala i mrzela, Sati može da sklopi svoju priču i da je celu ispriča. Rafaela Bakolini (Raffaella Baccolini) kaže da se Sati „mora pomiriti sa sopstvenom istorijom i bolnim sećanjima, posebno sa smrću svoje partnerke Pao, koju su ubili teranski verski fundamentalisti. U potrazi čiji je cilj da povrati i sačuva jednu ugroženu istoriju, ona otkriva da mora da stvori sopstveno pričanje“ (Baccolini, 2003: 23). Objašnjavajući svoj život Jari, ona ga objašnjava sebi. Nastavlja priču od mesta na kome se ona u njenom sećanju uvek prekidala i približava se najbolnijoj tački - svojoj tragičnoj ljubavi. „Do ovog mesta bilo je prilično lako. Do mesta iza koga nikada nije zakoračila. Priča koju je pričala samo sebi, jedino u tišini, pre no što bi utonula u san, okončavala se ovde" (Legvin, 2000: 178). Sati mora da izrekne ono za šta je mislila da je neizrecivo (zapravo ono neizrečeno) kako bi došla do istinski neizrecivog: „Nije u priči mogla da zaobiđe stvar ili da je izbegne. Morala je da prođe pričom kroz nju. Morala je da je ispriča“ (Legvin, 2000: 179).

Kada kaže „Zvala se Pao“, počinje da plače. Izgovaranje godinama neizgovorenog imena probija poslednju barijeru u njoj i priča će poteći, a dugo zabranjivane, poricane i potiskivane emocije se izliti. Kada je završila, „Sedeli su u tišini. U nedrima planine. U pećinama punim bića. [...] Ćutanje koje su delili posle izgovorenih reči bilo je spokojno, predstavljalo je zasluženi blagoslov“ (Legvin, 2000: 181). Kroz reči su došli do tišine. Kada je posle ovog razgovora izašla iz pećine, vreme je blago, a sneg je prekrio sve tragove na platou ispred pećina. Dolazi do ivice platoa i zagleda se u ambis. U praznini provalije između dve planine gleda neprestani ples snega nošenog vetrom. „Ostala je tu dugo da stoji i da posmatra svetlost kako gasne“ (Legvin, 2000: 182).

Hod ka smrti ega i ulivanju u more bivstva odvija se kroz sukcesivno ulivanje odeljenih delova bića u jedno - kroz rušenje granica između njih i kroz njihovo nestajanje kao zasebnih entiteta. Lao Ci o ovome progovara kroz metaforu vode:

Svemu pod nebom utoka je dao,

kao što i potoci i male reke u (velike) reke i mora utiču.

(Velike) reke i mora, pošto borave nisko,

vladari su manjih tokova. (2003: 50) 
Jednostavnost je poništavanje ega koje ne treba smatrati regresijom. Poništavanje ega je zapravo otvaranje za sopstvo koje je neuporedivo veće od ovog ja. Emocija prestaje da vuče na jednu, um na drugu stranu. Njihova obesna vlast nad sopstvom prestaje. Pojedinac ih mirom koji isijava iz središta njegovog bića privlači i okuplja u tom središtu. On postaje jedno biće - jedan tok koji moćno i mirno ide naniže da se kroz samouništenje ponovo rodi. U odeljku „Dao mudrosti“ studije Psihologija zrele duhovnosti (The Psychology of Mature Spirituality) izlaže se koncept „doživotnog razvoja koji teži celovitosti, opisan u daoizmu. [...] Na kraju, smrt okončava ovaj razvojni ciklus, vraćajući nas u stanje celovitosti iz kojeg smo istupili rođenjem“ (Rosen/ Crouse, 2000: 120). Monitor je, prevazišavši sebe i potpuno se ogolivši, ispričavši sve, prećutkivanje zamenio ćutanjem, tišinom. Velikom, nadljudskom tišinom pećina bića - izvora Pričanja i izvora bivanja. Posle razgovora, on kaže "Hvala ti, joze Sati" i nedugo potom skače u ambis između dve planine.

Jungovoj i daoističkoj perspektivi razvoja lične mudrosti zajedničko je stanovište da se mudrost postiže odbacivanjem ega i uspostavljanjem veze sa sopstvenim božanskim središtem (Rosen/Crouse, 2000: 127). Sati se uspešnim razrešavanjem konflikta sa Monitorom oslobađa vezanosti za ego, a kroz kontakt sa sistemom Pričanja stupa u dodir sa svojim duhovnim središtem. Na ovaj način oslobođena, ona je shvatila da je posledica njene opterećenosti egom i prošlošću bilo pasivno prepuštanje društvu i svetu bez aktivnog stvaralačkog manipulisanja njime koje podrazumeva učestvovanje u njemu, ovladavanje njime, njegovo osmišljavanje i oblikovanje za sebe, svojevrsno stvaranje kosmosa od haosa - i to ju je odvelo u potpunu dezorijentisanost i očaj. „Objektivni“ posmatrač sveta nužno je ophrvan količinom, silinom, neusklađenošću i nepomirljivošću utisaka. Sati je morala da pronađe način za ovladavanje utiscima. Vežbanje kontrole misli i osećanja, uočavanje njihovih mehanizama i ovladavanje njima, cilj su kako daoizma tako i budizma. ${ }^{7}$ Stoga, pokazuje se, posmatrač naizgled paradoksalno ispunjava svoju pravu ulogu tek kada postane učesnik. Posmatranje bez učestvovanja nije moguće. U Psihoanalizi na Istoku i Zapadu (Psychoanalysis East and West) Alan Vots zapaža da „u svim oblastima nauke, od fizike do psihologije, postaje sve jasnije da posmatrati svet znači učestvovati $u$ njemu, i da ovo, ma koliko u prvi mah delovalo kao da osujećuje, predstavlja najvažniju od svih smernica za unapređivanje znanja“ (Watts, 1975: 88). ${ }^{8}$ Tek istinsko prepuštanje svetu, koje podrazumeva aktivno stvaralačko učestvovanje u njemu, vodi do ispredanja niti smisla od paučine haosa, a subjektivno stvaranje sveta ne samo da ga čini podnošljivim, već ga otvara i kao prostor samoispoljavanja i kreativnosti.

Po povratku sa Silonga u Dovzu, promena u Sati je jasno uočljiva. Prešla je put od preplašenog nesigurnog deteta koje je u svemu zavisilo od nadređenog izaslanika Ekumena Tong Ova i u njemu videlo jedinu sigurnost do samouverene stabilne oso-

7 Pored daoističkih elemenata, ovaj roman obiluje i budističkim referencama. Satin put se, na primer, može iz budističkog ugla analizirati kao put ka oslobađanju od patnje koji se sastoji od spoznavanja patnje, prolaska kroz patnju, i prevazilaženja patnje.

8 Istočnjačko učenje o iluzornosti objektivnog posmatranja i spoznavanja sveta potvrdila je i kvantna fizika otkrićem da misao eksperimentatora utiče na subatomske čestice koje se posmatraju (Capra, 1989: 31; Pušić, 2015: 26). 
be koja se suprotstavlja njegovom mišljenju i otkriva dublje razumevanje načina na koji funkcioniše Aka. „Moraćeš da mi veruješ“, kaže i počinje da objašnjava Ovu kako treba nastupiti i koji su sledeći koraci Ekumena u odnosima s Akom. Na samom kraju knjige otpočinju pregovori sa akanskom vladom: „JJarin] život bio je podastrt ovom pogađanju. Njegov život, Paoin život. Bili su to neopipljivi, neproračunljivi ulozi. Novac pretvoren u pepeo, odbačeno zlato. Koraci po vazduhu.“ (Legvin, 2000: 200).

Rihard Vilhelm u svom komentaru neodaoističke Tajne zlatnog cveta objašnjava da se upravo u neodricanju od ličnog aktivnog učestvovanja u svetu daoizam fundamentalno razlikuje od budizma: „U budizmu je [...] povratak u nirvanu povezan sa potpunim poništavanjem ega koji je, kao i svet, tek iluzija. Ako nirvana ne može da se objasni kao smrt, prekid, ipak je striktno transcedentna. U taoizmu, s druge strane, cilj je da se u preobraženom obliku sačuva ideja osobe“ (1982: 53). Iako je budizam izvršio značajan uticaj na ovaj roman Ursule Le Gvin, u krajnjem ishodu ona svoju junakinju definiše nedvosmisleno daoistički time što dostizanje jednostavnosti i razrešenje psiholoških nedostatnosti ne vodi povlačenju iz sveta, već naprotiv punijem i smislenijem učestvovanju u njemu.

\section{Literatura}

Baccolini, R. (2003). 'A useful knowledge of the present is rooted in the past': Memory and Historical Reconciliation in Ursula K. Le Guin's The Telling. In R. Baccolini \& T. Moylan (Eds.), Dark Horizons: Science Fiction and the Dystopian Imagination (pp. 13-34). New York: Routledge.

Bernardo, S. M., Murphy, G. J. (2006). Ursula K. Le Guin: A Critical Companion. Westport: Greenwood Press.

Cadden, M. (2005). Ursula K. Le Guin Beyond Genre: Fiction for Children and Adults. New York and London: Routledge.

Capra, F. (1989). Tao fizike. Beograd: Opus.

Jung, C. G. (1958). Psychology and Religion: West and East. Princeton: Princeton University Press.

Jung, K. G. (2015). Sećanja, snovi, razmišljanja. Beograd: Atos.

Lao C. (2003). Knjiga o Daou i Deu (R. Pušić, prev.). Beograd: Plato.

Legvin, U. (2000). Pričanje. Beograd: Polaris.

Legvin, U. (2013). Dvanaest četvrti vetra. Zrenjanin: Zardoz.

Pušić, R. (2012). Ptica u suncu: osnovi kineske civilizacije. Beograd: Čigoja.

Pušić, R. (2015). Prazne ruke. Beograd: Čigoja.

Rosen, D. H., Crouse, E. M. (2000). The Tao of Wisdom: Integration of Taoism and the Psychologies of Jung, Erikson and Maslow. In P. Young-Eisendrath \& M. E. Miller (Eds.), The Psychology of Mature Spirituality: Integrity, Wisdom, Transcendence (pp. 120-129). London and Philadelphia: Routledge.

Suzuki, D. T., From, E. (1973). Zen budizam i psihoanaliza. Beograd: Nolit.

Vilhelm, R. (1982). Poreklo i sadržaj Tajne zlatnog cveta. U Tajna zlatnog cveta (str. 43-54). Niš: Gradina. 
Vučković, M. (2020). Prošlost, sadašnjost i budućnost - priča o Pričanju Ursule Le Gvin. Polja: časopis za književnost i teoriju, 524, 142-149.

Watts, A. (1975). Psychotherapy East and West. New York: Random House.

Watts, A. (1981). Tao: The Watercourse Way. London: Penguin Books.

Young-Eisendrath, P. (2000). Psychotherapy as Ordinary Transcendence: The Unspeakable and the Unspoken. In P. Young-Eisendrath \& M. E. Miller (Eds.), The Psychology of Mature Spirituality: Integrity, Wisdom, Transcendence (pp. 133-144). London and Philadelphia: Routledge.

Zhuangzi. (2013). The Complete Works of Zhuangzi (B. Watson, Trans.). New York: Columbia University Press.

\section{Artea D. Panajotović}

\section{Summary}

\section{A DAOIST JOURNEY TO SIMPLICITY IN URSULAK. LE GUIN'S THE TELLING}

Despite the common-knowledge status of Ursula K. Le Guin's connection with the Chinese philosophical system of Daoism, this relationship has never been thoroughly explored. With the aim of shedding light on a small aspect of this complex relationship, the paper examines the motif of simplicity, one of the key concepts of Daoist philosophy and the foundation of Daoist practice, in The Telling (2000), the last novel of the Hainish cycle. On the level of character development, the process of attaining simplicity finds its expression in the personal growth of the protagonist. The exploratory mission of Sutty Dass, the Ekumen's Observer on the planet Aka, is a journey of self-awareness and personal transformation, a personal quest for simplicity. Two key points of this journey are Sutty's acquaintance with the Telling, the ancient, now outlawed, philosophical and religious system, and her complex relationship with the novel's antagonist, an employee of the new totalitarian system which now rules the planet. The analysis shows that Sutty Dass's attainment of simplicity brings about the transformation of her false (nongenuine) self into her true (genuine) self and reveals how profoundly Ursula K. Le Guin's understanding of the concept of simplicity is permeated by Daoist theory and practice.

\section{Key words:}

Chinese philosophy, science fiction, Dao, wu wei, character transformation 